\title{
Rival Friends: Sidonius Apollinaris and Literary Competitiveness in Late Antique Gaul
}

\author{
Schwitter, Raphael
}

\begin{abstract}
DOI: https://doi.org/10.1353/jla.2020.0012
Posted at the Zurich Open Repository and Archive, University of Zurich ZORA URL: https://doi.org/10.5167/uzh-197100

Journal Article

Published Version
\end{abstract}

Abstract: Published by Johns Hopkins University PressDOI:For additional information about this articleAccess provided at 2 Apr 2020 08:25 GMT with no institutional affiliationhttps://doi.org/10.1353/jla.2020.0012

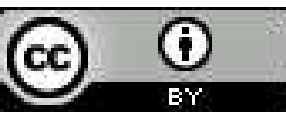

The following work is licensed under a Creative Commons: Attribution 4.0 International (CC BY 4.0) License.

Originally published at:

Schwitter, Raphael (2020). Rival Friends: Sidonius Apollinaris and Literary Competitiveness in Late Antique Gaul. Journal of Late Antiquity, 13(1):73-93.

DOI: https://doi.org/10.1353/jla.2020.0012 


\section{PROJECT MUSE}

Rival Friends: Sidonius Apollinaris and Literary

Competitiveness in Late Antique Gaul

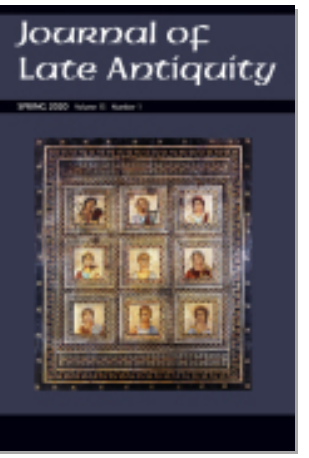

Journal of Late Antiquity, Volume 13, Number 1, Spring 2020, pp. 73-93 (Article)

Published by Johns Hopkins University Press

DOI: https://doi.org/10.1353/jla.2020.0012

$\Rightarrow$ For additional information about this article https://muse.jhu.edu/article/752069 


\title{
Rival Friends: Sidonius Apollinaris and Literary Competitiveness in Late Antique Gaul
}

\begin{abstract}
The objective of the following discussion is to illuminate the status and pertinence that poetic contention and literary rivalry maintained within late antique peer groups. Competition and rivalry were a natural part of the day-to-day world of the late antique aristocracy. In the friendship groups of Ausonius, Symmachus, or Sidonius Apollinaris, aristocratic competition was played out primarily in demanding literary short form compositions, authored in time of leisure. Despite its placement in a context of competitiveness, the agonistic coloring of late antique nugae literature is scarcely perceptible in the texts. This is, however, the result of a semantic reorganization in the course of the transmission of what were once occasional pieces in the medium of the book. In deliberate contrast to the favored interpretation of this literature as the expression of artfully learned playfulness, this reading recalls the agonistic context of the initial production and reception in order to better understand the significance and function of this literature as an aristocratic mode of interaction.
\end{abstract}

\section{Introduction}

Contest and competition were pervasive in Graeco-Roman culture. The form and scene and the social groups participating may vary, but the pressure and even the social necessity to measure oneself against others forms a functional, common denominator to these struggles. ${ }^{1}$ Within the Roman senatorial aristocracy, where modes of interaction were traditionally determined by a pragmatic combination of competition and co-operation, clearly defined areas of

The first draft of this paper was presented in German. I am deeply grateful to David van Schoor for his diligent translation of the revised article, and to Sigrid Mratschek for her valuable comments.

${ }^{1}$ Competition is ubiquitous in all cultures and in every period. For a comparative overview of competition in antiquity see Fisher and Van Wees 2011. On competition as natural part of Roman aristocratic life see, for example, Wiseman 1985 and Barton 2001, 35 and 850-86; on rivalry and ambition as topic in Roman legendary history, see Neel 2012. 
contest were established over time. Here, interpersonal competition could take place more or less without conflict.

The domain of literature gained increasingly in significance in the upper aristocratic contests for prestige, status and recognition from the early imperial period. The development of literature as field of contest by the senatorial elite in the first and second centuries CE went along with the revaluation and promotion of private otium which became important for how aristocrats distinguished themselves from one another and competed to be the best. In the context of senatorial strategies of self-presentation of the imperial period, the works of the Younger Pliny demonstrate in exemplary fashion the meaning of studia litterarum as pursued in otium. ${ }^{2}$ Alongside oratory and letter-writing, minor poetic forms, which authors confidently published in collections, gained in importance. Pliny moved in a milieu of the like-minded, who along with their numerous juristic, political, and administrative duties, found time for the composition of poetical nugae in the tradition of Catullus. ${ }^{3}$ At the same time, competition between authors and the critical assessment of their works represented not only an indispensable aspect of literary enjoyment at the time, but the exhibiting of literary ability was also an important means of social distinction. Such exchanges took place within the practice of amicitia, which at Rome retained a fundamentally competitive character. ${ }^{4}$

The objective of the following discussion is to illuminate the status that poetic competition and literary rivalry maintained within late antique peer groups. The late antique republic of letters - at least for that section which was structurally tied to the aristocratic authority of amicitia and otiumdemonstrates clear analogies with the imperial period in this regard, a point well recognized by contemporaries and one renegotiated and manipulated by literary means. ${ }^{5}$ Scarcely anything had changed in regard to the setting of or form taken by upper aristocratic competition carried out in the literary field. This was played out in the friendship groups of Ausonius, Symmachus, and Sidonius Apollinaris primarily in those demanding short form compositions: the epigram, cento, technopaignia and, not least, letters. These

\footnotetext{
2 See, for example, Krasser 1995; Leach 2003; Künzer 2016, 177-291; Neger 2016; Mratschek 2018. For a comprehensive study of the Roman intellectual history of otium, see André 1966; also Wiegandt 2016.

${ }^{3}$ On this milieu see, for example, Fein 1993, 126-51; for Pliny's poetry in the tradition of Catullus see Hershkowitz 1995; Roller 1998; Auhagen 2003.

${ }^{4}$ Striving to outdo one another in friendliness and offers of favors is an established part of the theory of friendship; see, for example, Cic. Amic. 32.

${ }^{5}$ On the continuous cultural endeavouring of a small, highly privileged elite in the fourth and fifth centuries CE; see Schwitter 2015, 81-93. On Sidonius's recourse to imperial age Bildungskultur and the implied equivalence of his readers with the nobility of the second century CE, see Mratschek 2008; on Ausonius, see especially Sowers 2016.
} 
characterized the otium litteratum, that exclusive space of communication of the educated elite. ${ }^{6}$

\section{Nugae and Poetic Competitiveness}

Although late antique nugae literature clearly is to a great extent competitive, modern scholars almost exclusively read it as the expression of artfully learned playfulness (lusus). ${ }^{7}$ At the same time, they have emphasised the unifying function that this literature exercised on the late antique elites in a time of extensive social, political, and economic upheaval. In this reading, the production and exchange of short-form poetry and letters, along the traditional lines of Greco-Roman culture, assured the social and cultural cohesion of this tightly knit group. ${ }^{8}$

Knowledge of the agonistic context of the initial production and reception of many of the surviving short-form poems and letters is not a necessary condition for a rich reading of these texts. An appropriate appreciation of that context, however, will help to better understand the significance and the function of this literature as an aristocratic mode of interaction. At the same time, insights into the possible intentions and interests, which were decisive in the editing of the transmitted opuscula collections, may present themselves. For the favored interpretation of recent scholarship of literary nugae as a component of the aristocratic cult of friendship corresponds exactly to the style of reading to which the authors of the surviving collections of poems guide their readers. ${ }^{9}$ That the competitiveness of the original context is scarcely perceptible in the texts any longer is the result of a subsequent semantic reorganization, a reinterpretation designed for a specific secondary reception. This occurred in the course of the transmission of what were once occasional pieces in the medium of the book. When they were editorially unified and smoothed into the form of the libellus, that rivalry latent in a context of occasional composition was displaced, or at any rate obscured, by the very

${ }^{6}$ For this kind of literature, Sidonius coined the term otiositates (Ep. 2.10.3); see Hindermann in this volume. He generally refers to his poetry as iocus, nugae, ineptiae (Sid. Ap. Ep. 3.3.6, 3.14.1, 4.8.5, 8.9.4, 8.11.2, 9.13.6, 9.16.3 line 33). On otium litteratum in Sidonius, see André 2006 and Hindermann in this volume; for an overview of late antique occasional poetry, see Mulligan 2018.

${ }^{7}$ For example, La Penna 1993; La Penna 1995; Malaspina 2002; Styka 2015; Guipponi-Gineste 2017. Earlier scholarship read this literature as the senseless squabbling of poets of middling talents; see Loyen 1943, 56-105 and 166: "une puérilité . . . d'un esprit superficiel."

${ }^{8}$ Expressed succinctly by Malaspina 2002, 201: "La poesia era infatti destinata anzitutto a coltivare l'amicizia in una società lacerata." See also Mathisen 1993, 105-18.

${ }^{9}$ See, for example, Auson. Ep. 13.67, Griphus praef., Cent. nupt. Ep., Technop. 1; Sid. Ap. Carm. 9.9-15, Ep. 4.18.2, 7.7.1, 9.16.3.41-48; Ven. Fort. Carm. praef. Much work is being carried out on the cult of friendship of the late antique aristocracy; see, with special focus on epistolography, Mathisen 1981; Bruggisser 1993; Le Jan 2004; Styka 2016. 
function of the poetry so as to form, consolidate, and memorialize a specific literary community. When we exclusively emphasize the lusus theme, it is the playful and convivial aspect of short-form poetry (and thereby an atmosphere of happy, consenting solidarity, a harmony of voices, as it were) which is foregrounded. ${ }^{10}$ In this way, not only do these texts become inscribed in the tradition of Roman nugae literature but also an ideal readership is predicated, one which supposedly ought to consume the collections produced in just the manner intended. ${ }^{11}$

Having established this background, in what follows I shall call to mind the agonistic coloring of late antique nugae literature. By means of the pertinent examples that arise, it will be demonstrated how aristocrats like Sidonius Apollinaris vied with one another for honor, regard, and prestige in the private sphere of literary otium.

\section{Rivalry between Friends and Foes}

We must distinguish between two principal kinds of literary competitiveness: there is, on the one hand, the competition between political rivals and personal enemies, and on the other, that between friends. The latter are competing, then, within a particular peer group, bound together through relations of friendship. The first kind will only be very briefly touched on here. Satire, understood in Late Antiquity primarily as the poetry of opprobrium and personal invective, proved itself a likely literary vehicle against political rivals and personal enemies. In this mold, it was a favored form for Sidonius Apollinaris, both in verse and in prose. ${ }^{12}$ From the perspective of aristocratic rivalry, Ep. 1.11 is rather pertinent. Here Sidonius tells of a mordant verse satire (charta . . versuum plena satiricorum mordacium), which had been anonymously published in Arles in the year 461. The infuriated targets of the attack, who had recognized themselves despite the omission of any names, had ascribed its authorship to Sidonius, known as an author of satires. ${ }^{13} \mathrm{At}$

\footnotetext{
${ }^{10}$ See especially Sid. Ap. Ep. 1.5.3. On the significance of regular convivia for elite group dynamic, see, for example, Schwitter 2015, 193 with further bibliography. On the significance of common reading for educated society in late antiquity see Eigler 2003, 114-15, 126-27.

${ }^{11}$ Sidonius's Carmina minora collection demonstrates this in exemplary fashion: introductory (Carm. 9) and concluding (Carm. 24) poems define the collection programmatically as nugae. In Carm. 24, the libellus is sent to individual members of Sidonius's circle of friends as propempticon, and their community is thereby immortalized. On Carm. 9, see the detailed discussion of Hernández Lobato 2012, 401-49; for Carm. 24, see Santelia 2002; for the Carmina minora in general, see Condorelli 2008, 79-187. Ausonius's nugae are a similar case; Sowers 2016 analyzes how Ausonius invites his friends to participate in the production, editing, and circulation of his poetry.

${ }^{12}$ See Blänsdorf 1993.

${ }^{13}$ On this much regarded letter, see Simons 2008; Hanaghan 2019, 108-12.
} 
a banquet of the Emperor Majorian (reigned from 457 to $461 \mathrm{CE}$ ) who was staying in Gaul at the time, Sidonius managed, however, to acquit himself of the charges by means of an impromptu poem. The manner in which Sidonius evokes the scene of the banquet brings out not only the latently aggressive competitiveness of a situation in which guests and courtiers are clamoring for the attention of the emperor; his victory also vividly shows the consequences for his main opponent, whose anonymity was not preserved on publication, of being publicly exposed. His loss of face through the inclusion of the letter in the collection, was, as it were, immortalized. ${ }^{14}$

The second kind, rivalry in Cicero's sense of bonesta certatio, ${ }^{15}$ took various forms within educated circles. It expressed itself predominantly in reciprocal favors and acts of friendship, in gifts or in a particular form of hospitality. ${ }^{16}$ Exchange of gestures of friendship had always formed part of the competition for influence and honors at Rome. ${ }^{17}$ Overt evidence of this latent facing off, which could quickly flip into enmity, ${ }^{18}$ is found sporadically in Sidonius's letter collection. In Ep. 2.9.3, for example, he reports how two hosts competed over him. ${ }^{19}$ However, any potential competitive impulse is irrelevant here. Together with Ep. 2.2 and 2.13, the epistle forms a group of writings within the second book in which the exemplary hospitality of a member of the Gallo-Roman elite is depicted. ${ }^{20}$ Within the context of Sidonius's literary œuvre these letters belong with those pieces which openly celebrate the network community of neighboring, villa-owning friends from the upper classes. ${ }^{21}$ This idealizing domestication or neutralizing of any rivalrous emotions between these figures-here designated "charming" (grata)—is, as will be shown, thoroughly in keeping with Sidonius's further treatment of the theme in his letters.

Sidonius describes the befitting manner of friendly rivalry in a short letter of salutation to his uncles Simplicius and Apollinaris, in which the bearer of

\footnotetext{
${ }^{14}$ See also Sidonius's repeated vilification of the Roman collaborator, Seronatus: Ep. 2.1.1 (Catilina saeculi nostri), 5.13.1 (belua), 5.13.3 (bestia); on Seronatus, see Fascione 2016.

${ }^{15}$ Cic. Amic. 32.

${ }^{16}$ See, for example, Sid. Ap. Ep. 1.5.2, 2.11.1, 3.1.1, 7.2.5. On the exchange of gifts among the late Roman aristocracy, see Wood 2000; Shanzer 2001.

${ }^{17}$ See, for example, Mattern-Parkes 2001, 182: "The gift, as well as the insult, can be a form of challenge and can just as easily spark a never-ending cycle of reciprocity." See further Rollinger 2014, 114-21.

${ }^{18}$ Cic. Amic. 34.

${ }^{19}$ Ep. 2.9.3. See Hanaghan's discussion of the letter in this volume.

${ }^{20}$ For the readership of this collection, there opens up a further sphere of competition here with Sidonius as manifest successor to Pliny. See further to this point below.

${ }^{21}$ For example, Sid. Ap. Carm. 24, Ep. 8.11 and 8.12. On the circles of Sidonius's addressees, see Loyen 1943, 65-92.
} 
the note, the priest Faustinus, is introduced to the two addressees as a friend from Sidonius's youth. Many times had they shared both serious and lighthearted experiences and in youthful camaraderie measured themselves one against the other in ball games, at dice, in running and jumping, swimming, and hunting:

He is my brother by the equality of our birth, my friend by the likeness of our minds. Many a time have I shared jest and earnest with him, and in the bygone days of our youth we contended in ballgames and dicing, jumping and running, hunting and swimming, with no guile in our rivalry, for our love never faltered. ${ }^{22}$

The sentence is as tight as it is loaded: ellipsis and parallelism mark the first two cola, an asyndetic series the last section. Contentio, the central idea, is accented through its terminal placement, the appositional sancta, through alliteration. The fair, friendly manner of competition between them is emphasized, and this is defined by the friendly bond shared between the two adversaries (manente caritate). In Ep. 8.11.1, Sidonius evokes the same kind of relationship in a comparable context. The relationship between the two youths is further differentiated in the lines that follow, as the hierarchically significant question of age is introduced: Faustinus was older and therefore senior to Sidonius. Yet, he emulated him more from love than out of respect owed. $^{23}$ This kind of relationship would come to stand in the mind of the reading public as the standard for aristocratic rivalry in the sphere of otium.

\section{Poetic Competition in Convivial Contexts}

It is clear from Ep. 9.13 that an affectionate, friendly rivalry, such as that described by Sidonius in only games and sports, was anticipated also in the field of literary activity. ${ }^{24}$ Here Sidonius tells the young Tonantius of a ban-

22 Sid. Ap. Ep. 4.4: Hic meus frater natalium parilitate, amicus animorum similitudine; saepe cum hoc seria, saepe etiam ioca miscui; cumque abhinc retro iuvenes eramus, in pila, in tesseris, saltibus, cursu, venatu, natatu sancta semper ambobus, quia manente caritate, contentio. Sidonius's letters and poems are quoted after Loyen's Budé edition; translations are based on Anderson 1936, with occasional modifications.

${ }^{23}$ Sid. Ap. Ep. 4.4.1: "He was indeed older than I, but only so much as to make me glad to imitate him without the necessity of treating him with deference; at the same time he on his part found it all the more charming to feel that he was loved rather than made a sort of idol" (Mibi quidem maior bic natu, tantum tamen ut eum non tam honorari necesse esset quam delectaret imitari; simul et ipse hinc amplius capiebatur, quod se diligi magis quam quasi coli intellegebat).

${ }^{24}$ On this letter, which is much regarded on account of its metaliterary revelance, see Guillaume-Coirier 2000; Consolino 2011; Condorelli 2013; Guipponi-Gineste 2017; Egelhaaf-Gaiser 2018, 274-82. See also Hanaghan in this volume. 
quet, which had taken place in the house of a friend twenty years before in the time of the emperor Majorian. During a break between the courses, he and three fellow poets had written poems extemporaneously about a book, the author of which, a senior official of the imperial court, had earlier presented them. ${ }^{25}$ That Sidonius and his fellow poets were caught up in a proper poetic certamen is not explicitly stated, but it is implied in the description of the proceedings:

The only thing that delayed the start was the choosing of our meters by lot; for although the subject-matter was the same for all, yet, as was proper for devoted colleagues, we resolved that the poems of the several competitors should not be in the same metrical form, so that none of us whose piece might be poorer than the others should be stung first with shame and later with envy. For in any case where a reciter of his poetry, no matter who, composes in the same meter as his rivals, it can more easily be discerned whether he also writes with the same talent. ${ }^{26}$

Two things are especially conspicuous here: one, the spontaneity of the poetic performance taking place in front of an audience, evident in the dividing by lot of metrical forms; and another, the collegiality of the contest, where what counts is the avoidance through fairness and consideration of any negative feelings (verecundia, invidia) cropping up amongst the participants. No one was to lose face in public; pleasure in competitive participation was the binding precondition of it all. Whether, in fact, this contest really did play itself out so harmoniously must remain an open question. Sidonius may have consciously downplayed the competitiveness of it in his report. For this illustrative passage serves clearly as an appeal: the letter's addressee, Tonantius, was adbuc iuvenis and thus in a comparable situation to that of Sidonius at the time of the reported banquet.

The letter is Sidonius's response to the young man's request to send him some asclepiads on the model of Horace for recitation inter bibendum. ${ }^{27}$ Referring to his age and to the dignity of his bishop's office, Sidonius turns down this request with an artful, polymetric recusatio over twenty-eight verses. In keeping with his own standing and role, he instructs the young man rather

${ }^{25}$ On the collegium poetarum gathered there, see Styka 2015.

${ }^{26}$ Sid. Ap. Ep. 9.13.5: Id morae tantum, dum genera metrorum sorte partimur. Placuit namque pro caritate collegii, licet omnibus eadem scribendi materia existeret, non uno tamen epigrammata singulorum genere proferri, ne quispiam nostrum, qui ceteris dixisset exilius, verecundia primum, post morderetur invidia. Etenim citius agnoscitur in quocumque recitante, si quo ceteri metro canat, an eo quoque scribat ingenio.

${ }^{27}$ Sid. Ap. Ep. 9.13.2. Banquets constitute an ideal space for the reception of short form poetry; see, for example, Sid. Ap. Carm. 22.5; Ep. 1.11.13-15. 
to devote himself to religious stories at dinner parties in the future. Should this, though, seem too unattractive on account of his youth, he ought to linger awhile on Apuleius's "Riddles for Dinner Parties" (conviviales quaestiones), solve them himself, and pass them on to others for solving. ${ }^{28}$ Here, likewise, a group contest is implied. The riddle was prized in the Graeco-Roman cultural scene as a competitive intellectual game at drinking parties. The survival of this tradition in the Latin West is attested in the riddle verses of Symphosius, which in his preface are designated as humorous poems for parties that had been composed impromptu at the Saturnalia. Sidonius's narration of the poetical certamen appears to situate itself in this living tradition: he continues his instructions to the addressee on the proper behavior at banquets and illustrates this with just that topic, which seems primarily to interest the young man, that is the literary contest inter amicos. ${ }^{29}$

The sancta contentio of Ep. 4.4 ought to be understood as affirmative here too: it must lead Tonantius on to a concept of literary aemulatio that is sensitive to the value of friendship, one not aiming for the disparagement or social humiliation of adversaries but one that instead, as in sports, allows for the correct evaluation of one's own abilities through competitive comparison with others and at the same time wins praise and recognition from an impartial audience. The improvised poem, included along with the letter, might have inspired the young man to diligent practice. The meter is anacreontic dimeter. Quite rare in Latin poetry, it attests to the high level of competitively celebrated poetic ars in late antique educated circles. ${ }^{30}$ Despite the lack of direct intertextual allusions, the Catullan imaginary of in-group competition at a dinner party becomes immediately clear here. ${ }^{31}$ The convivium of a poetic community now past, which is evoked in the letter, becomes an exemplary exhibition space for Sidonius's own literary creativity. For Tonantius, the primary reader, it means that he must compete not only with his peers but first and foremost with Sidonius. For the readers of the ninth book, the letter opens a series dominated by the theme of convivium with interposed lyric showing off the wide literary range of Sidonius's body of work, which is recapitulated in the final letter. ${ }^{32}$ Thus, the conjuring up of a banquet scene from the irretrievable past must also be read against the background of the author's intentions in organizing his epistolary collection. The staging of the poetic certamen as friendly lusus is an element of an idealized reality, one brought

${ }^{28}$ Sid. Ap. Ep. 9.13.3. See Condorelli 2013, 120-21.

${ }^{29}$ Sid. Ap. Ep. 9.13.4-5.

${ }^{30}$ Discussed by Onorato 2017.

${ }^{31}$ See Catull. Carm. 50.

${ }^{32}$ Sid. Ap. Ep. 9.13-16. For the assessment of the feast as space of remembrance and commemoration in the last two books of letters, see Egelhaaf-Gaiser 2018. 
before the eyes of the readership by Sidonius and thus only in a qualified sense coherent with the historical realities of aristocratic competition.

Examples from other authors show that in Late Antiquity extemporising in convivial contexts was relatively common. One could thereby competitively display one's artfulness. Thus, Ausonius offers his wedding song in the letter of dedication to his Cento nuptialis as a quickly accomplished occasional poem (frivolum et nullius pretii opusculum . . . sine ingenii acumine et morae maturitate), ${ }^{33}$ owing its existence to a poetical contest with Emperor Valentinian I (reigned from 364 to $375 \mathrm{CE}$ ). ${ }^{34}$ It is quite significant here that the competitive context of composition exceptionally receives mention. As can be shown, reference to the occasional nature of the poem's composition and original reception serve as a preemptive apology for the striking obscenity of the piece. ${ }^{35}$ In Ausonius's Griphus ternarii numeri, on the other hand, a poetic play with the number three, which likewise came about over dinner, the competitive context is downplayed and instead, quite conventionally, the playful character of the moment emphasized. ${ }^{36}$ It is nevertheless fiendishly obscure and, when subsequently delivered to Symmachus as an epistolary gift, clearly meant to challenge the addressee's wit and wisdom.

Games of such a kind and the competitive context associated with them are happily deemed the province of youth by late antique authors, a domain from which the mature man abstains. This is expressed programmatically not only in the piece dedicatory to Sidonius's collection of minor poems (nugas temerarias . . . sparsit quas tenerae iocus iuventae), ${ }^{37}$ but also several times in the concluding epistles of his collection of letters. ${ }^{38}$ And still, even amid increasing age, the taste for literary combat and competitively taking the measure of one's powers endured amongst highly educated aristocrats. At Ep. 5.17, Sidonius explains to his addressee, the vir clarissimus Eriphius, how a notable epigram, which he had improvised at the request of Philomathius, Eriphius's father-in-law, had come about. In a long narratio, Sidonius tells his literary enthusiast friend of a feast in honor of Saint Justus in Lyon. During an intermission in the festivities the primi civium had gathered together in friendly conversation in the shady gardens of a neighboring mausoleum. They soon moved on to dice and ball games. The eager excitement of the

\footnotetext{
${ }^{33}$ Auson. Cent. Ep. 1 (ed. Green, OCT).

${ }^{34}$ Moroni 2006 discusses the origin and meaning of the work within the political and cultural context of Valentinian I.

${ }^{35}$ On this, see Schwitter 2016.

${ }^{36}$ Auson. Griph. Praef. 14-27 (ed. Green, OCT).

37 Sid. Ap. Carm. 9.9-10.

${ }^{38}$ Sid. Ap. Ep. 9.12, 9.13, 9.16.41-48. On the bishop Sidonius's distancing of himself from the poems of occasion of his youth, see Egelhaaf-Gaiser 2011, 275-79.
} 
participants is described in comically military terms by Sidonius, who himself joined in with the ball games. The high point of it all is the satirical depiction of Philomathius who, despite his advanced age, tries his hand at ball. The epic comparison with the grizzled Acestes, who takes part in the archery contest in Aeneid 5, establishes the competitive character of the scene. Quickly worn out, Philomathius is the first to retire; in order to spare him any embarrassment, Sidonius follows him off in an act of friendly loyalty. When a towel is brought at Philomathius's request, he asks Sidonius to compose off the cuff a tetrastich on it. Next, to the applause of their audience, follows a short, mischievous duel between the two, which is laid out in the letter in the form of excited dialogue. ${ }^{39}$ Sidonius meets Philomathius's demand in the end and the poem is copied down by a scriba.

A similar competitive situation is discernible in an epigram by Ennodius dealing with the same topic. ${ }^{40}$ There is a series of Ennodius's Carmina minora that in the manuscripts are expressly designated as extemporaneous poems. It is striking that often multiple variants on the same topic have been transmitted, on a drinking vessel, ${ }^{41}$ for instance, or on a Roman with the beard of a Goth. ${ }^{42}$ Not explicitly designated as extemporaneous pieces but preserved in multiple versions are another on an eel, ${ }^{43}$ which was so small that it fit in a pistachio shell, and still another on a desirable youth. ${ }^{44}$ We are left to speculate on the original context of composition of these poems, which stand quite obviously in the pre-Christian tradition of epigram. It would not be absurd, however, to locate some of these poems within the parameters of a convivial, festal event through which the multiple versions may be read as the productions of different poets participating in a certamen.

One also strove outside of convivial contexts to demonstrate one's own literary spontaneity. Thus, both Ausonius and Sidonius mention at many different places the respective origins of their letters and poems. ${ }^{45}$ In order to retain the approbation and recognition of the literary circles in which one moved, intensive training in techniques of improvised oratory and off-the-cuff

${ }^{39}$ Ep. 5.17.9.

${ }^{40}$ Ennod. Carm. 2.107; on Ennodius as representative of the Gallo-Roman elite, see Marconi 2013; on his epigrams di Rienzo 2005. His poetic opus is only partially transmitted; an introductory poem speaks for the likely existence of a nugae collection (Carm. $2.66=187 \mathrm{ed}$. Vogel, MGH $[A A] 7)$.

${ }^{41}$ Ennod. Carm. 2.25, 2.29-2.31, 2.103 (= 136-36b, 233 ed. Vogel, MGH [AA] 7).

${ }^{42}$ Ennod. Carm. 2.57-2.59 (= 182-82b ed. Vogel, MGH [AA] 7).

${ }^{43}$ Ennod. Carm. 2.46-2.49 (= 165-65c ed. Vogel, MGH [AA] 7).

${ }^{44}$ Ennod. Carm. 2.52-2.55 (= 180-80c ed. Vogel, MGH $[A A] 7$ ).

${ }^{45}$ Sid. Ap. Ep. 2.10.3, 3.12.4, 4.11.7; compare also Sid. Ap. Ep. 7.9.4, 8.11, 9.14.3. See Loyen $1943,101-3$. The topos of rapid and spontaneous poetic composition in the context of aristocratic otium is also found in Plin. Ep. 4.14.1-3. 
poetic composition was practiced. In a letter to the young Burgundio, Sidonius praises his studies in rhetoric, which enabled him to win "the admiration of the benevolent, the astonishment of the proud, the delaying applause of the cognoscenti" upon the delivery of an extemporized speech. ${ }^{46}$

\section{Competition in Epistolary Exchanges}

Feasts and occasions of sociability were doubtless an important space for late antique aristocrats to measure themselves against one another in an unconstrained atmosphere. The literary culture of the time did offer still further spaces for performance, where poetic ars, cultivated sermo, and literary competence could be exhibited through effective self-presentation. Along with the epigram, letter writing took on particular significance as a literary form for otium. ${ }^{47}$

The exchange of letters (in prose or as poetic epistle) required by the offcium amicitiae was regularly an opportunity for the demonstration of literary ability by the members of the Bildungselite in Late Antiquity. When, in practice, an occasion was lacking or no concrete exchange of information was intended, the opportunity taken to serve one's correspondent with brilliant, epistolary fare was seized upon. Letters could bridge geographical distances and create space for witty and spirited conversations in which a literary bout could be carried out. As in the cultivated table-talk, so usually did this kind of charm, humor, and witty repartee set the tone in private letters. ${ }^{48}$ Such writing, as in Sidonius's Ep. 9.13, could not only establish past gatherings in the collective memory but also make up for dinner companionship no longer possible and thus substitute for the literary contests celebrated at those feasts. We find this last point evidenced in two instances drawn from Sidonius's letters. ${ }^{49}$ In Ep. 1.8 to Candidianus, Sidonius is reciprocating a letter, which he had sent him on the occasion of his stay at Rome. There, Candidianus had apparently made mischievous fun of the unpleasant weather conditions of Sidonius's hometown of Lyon. Sidonius then responds to his friend's satirical depiction from his side with a biting satire of his correspondent's birthplace, the marsh plagued Ravenna-it is a topsy-turvy world, where the baths freeze

\footnotetext{
${ }^{46}$ Sid. Ap. Ep. 9.14.3: Quae quidem scripseras extemporaliter, admirabantur benivoli, mirabantur superbi, morabantur periti.

${ }^{47}$ As stressed by Cicero and Pliny; see Egelhaaf-Gaiser 2018, 258-61 and Hindermann in this volume.

${ }^{48}$ On this, with focus on the late Roman Republic, see Krostenko 2001.

${ }^{49}$ Another example is Carm. 23, the product of a poetic challenge by his friend Consentius (lines 5-7: Vltro in carmina tu tubam recludens / converso ordine versibus citasti / suetum ludere sic magis sodalem), who put Sidonius in debt by sending him an exquisite poem (from lines 20-28: Misisti ... dulces hendecasyllabos ... blando faenore Sollium ligasti).
} 
and the houses burn, where thieves keep vigil and officials sleep, where clerics practice usury and moneylenders chant the psalms. ${ }^{50}$ Thus, Sidonius's reply is the result of an intentional provocation by Candidianus, a literary challenge thrown down and meant to entice Sidonius to offer a suitable answer. ${ }^{51}$

A comparable example is to be found in Ep. 8.9, to the poet and rhetorician Lampridius. ${ }^{52}$ The letter dates to the period of Sidonius's exile in Bordeaux, whither he had been banned after Clermont had been handed over to the Goths. It is written in the form of a true prosimetrum in which verse and prose levels complement one another. Perhaps Lampridius's initial letter of inquiry took the same form as the preserved reply, which it elicited. Lampridius asked him for some jocular verses, but in the face of his circumstances at the time, Sidonius does not feel quite up to the task. His recusatio is extended throughout and further supported in the poem that he included. In the tone of a harangue, Lampridius is chided and upbraided for his tactless request:

Lampridius, glory of our poetry, why do you now try to stir to song Cirrha, or the Boeotian Muses, or the maids of Helicon at their inspired fountain dug by a stamp from the hoof of that neighing creature, the winged Pegasus? Why do you suddenly urge me to write, just as if I had carried the Delphicholy implements for the Delian god you worship, and as if I now were a new Apollo driving on my way the prophetic cauldron and tripod, the lyre, the quiver, the bow, and the gryphons, and shaking here the two-formed leafage with its berries, and there the clustering vine. You, my Tityrus, with your land restored to you, range through the groves of myrtle and planes, and so you strike your lyre, and both words and plectrum make the echoes ring with harmonious melody, my ministrel friend-so marvellous with string and voice and measure. ${ }^{53}$

Apostrophizing the addressee as a carefree Tityrus opens up a poetological dimension alongside the imminent political one. A passage in Ep. 2.2.14 makes clear that the responsions and contests of Vergilian shepherds are being

${ }^{50}$ Sid. Ap. Ep. 1.8.2.

${ }^{51}$ Topographical contrast as satirical motif appears at Ep. 8.12.1 too, where Sidonius wants to entice the military officer Trygetius to a banquet in Bordeaux.

${ }^{52}$ See Fo 1999; Schwitter 2015, 275-80.

${ }^{53}$ Sid. Ap. Ep. 8.9.5.1-16: Quid Cirrham vel Hyantias Camenas, / quid doctos Heliconidum liquores, / scalptos alitis hinnientis ictu, / nunc in carmina commovere temptas, / nostrae o Lampridius decus Thaliae, / et me scribere sic subinde cogis, / ac si Delphica Delio tulissem / instrumenta tuo novusque Apollo / cortinam, tripodas, chelyn, pharetras, / arcus grypas agam duplaeque frondis / hinc bacas quatiam vel hinc corymbos? / Tu iam, Tityre, rura post recepta I myrtos et platanona pervagatus / pulsas barbiton atque concinentes / ora et plectra tibi modos resultant, / chorda, voce, metro stupende psaltes. 
evoked and ought, by implication, to become a fruitful resource in the confrontation of the two poets. There, sleepless shepherds are said to cease from their song contests (carminum certamina) by night. A bucolic poetic, then, is brought into relief exclusively in its competitive form. ${ }^{54}$ The agonistic character of the exchange, in which Sidonius parries his friend's metrical provocatio with a compelling recusatio, is brought once more into the picture by means of an ambiguous comparison at the end of the letter: "There you have the poem for you to read as you take your ease, watching me struggle in the dust and sweat, while like a charioteer who has already won his crown you view the contest from the grandstand." ${ }^{55}$ As with the Tityrus comparison, the image of the circus arena is to be read on two levels: on the political, in the striving for the favor of the Gothic king, and on the poetological level, as a figuration of the poetical agon, which the two friends constantly kept up with each other. They are not quite on equal footing, however, as Sidonius has already previously noted. In sharp antithesis, he sets his own difficult position against the pleasant one in which Lampridius finds himself after his rehabilitation by Euric-it is impossible, therefore, to make a fair comparison of their poetry at this period. ${ }^{56}$ This form of epistolary exchange, in which one partner challenges the other in a mischievous, teasing tone to produce a reply, is evident not only with Sidonius but with other late antique letter writers too. The polymetric riddle letter that Ausonius sent to the poet Theon represents an artful instance of the type. ${ }^{57}$

Amongst the educated elite of Late Antiquity, the agonistic quality of letter exchange finds perhaps its clearest expression in the Plinian motif of the contest of mutual declarations of affection (certamen mutuae caritatis), the epistolary form of Cicero's bonesta certatio. ${ }^{58}$ This is found formulated explicitly in a letter by Symmachus:

Rivalry in performing the duties of friendship is sweet, and for that reason we are both rightly careful not to be outdone in the exchange of letters. So I rejoice that we are equals not only in the affection of our minds but also in the reciprocity of our correspondence. After this I will, nevertheless, take care that the balance and scale of my allegiance incline lower, lest it seem a kind of collusion in laziness always to be weighed as being in equilibrium.

${ }^{54}$ Sid. Ap. Ep. 2.2.14. The locus classicus is Verg. Ecl. 7.16.

${ }^{55}$ Ep. 8.9.6: En carmen, quod recenseas otiabundus nostrumque sudorem ac pulverem spectans veluti iam coronatus auriga de podio.

${ }^{56}$ Sid. Ap. Ep. 8.9.3.

${ }^{57}$ Auson. Ep. 14a (ed. Green, OCT); on this, see Schwitter 2015, 189-92.

${ }^{58}$ Plin. Ep. 7.7.2. See Cic. Fam. 7.31.1. 
And so I shall write more often, provided that there is a ready supply of gobetweens when I want one. ${ }^{59}$

Key terms for contest (dulce certamen, vincere) point to the amicable, sporting aspect; the metaphor of weighing (trutina, libra, aequa lanx) emphasizes quantifiable measurability in the rivalry over gestures of friendship performed (familiare officium). Symmachus employs the same agonistic terminology with various addressees at different times. ${ }^{60}$ Sidonius, too, often falls back on the topos. ${ }^{61}$ Ennodius, though resolutely refusing such certamina litteraria out of his feelings of Christian humilitas, implicitly confirms its continuing relevance for the Roman elite in Ostrogothic Italy. ${ }^{62}$ There was competition not only over the frequency of letters but also over their quality of style. As Symmachus says in another passage, "Even if I am inferior in elegance of language, I nevertheless try to be your equal in constancy of friendship." ${ }^{\prime 3}$ Rituals of friendship and literary competing here are united in the form of sancta contentio. Reflection on this practice within letters reveals the central value of the letter to the aristocratic culture of competition of the time.

As a medium of communication, the letter had long transcended its basic, practical function to inform and had taken on a central role in the cult of ostensible friendship among the late antique Bildungselite. The competition between letter writers took place in public, furthermore, just as that of the symposium or dinner party did. That same public also consumed the pieces contemporaneously as circulars or, at a later time, otherwise as part of a collection of letters. ${ }^{64}$ In the latter phase of reception, the agonistic context obtaining between individual correspondents necessarily shifts, however, into the background; for conventionally in collections of letters only single letters were included, and exchanges of letters only very seldom. This is surely also the reason why the competitive side of epistolography is generally so little appreciated in modern scholarship. In the few cases where we do have exchanges, a fundamentally agonistic constellation often comes to the fore.

\footnotetext{
${ }^{59}$ Symm. Ep. 1.92 (ed. Callu, Budé): Dulce certamen est familiaris officii et ideo iure ambo cavimus, ne alternis epistulis vinceremur. Gratulor igitur pares nos esse non solum adfectatione mentium, sed etiam vicissitudine litterarum. Curabo tamen posthac, ut obsequii mei trutina et libra praeponderet, ne videatur inertiae quoddam esse conludium semper aequa lance censeri. Itaque scribam saepius, modo facultas commeantium non desit optanti. Translation from Salzman and Roberts 2011, 167.

${ }^{60}$ Symm. Ep. 3.29, 4.72, 7.25, 8.22.

${ }^{61}$ Sid. Ap. Ep. 2.11.1, 6.3.1, 9.11.8.

${ }^{62}$ See Schröder 2007, 174-75.

${ }^{63}$ Symm. Ep. 4.26. See also Ep. 4.72, 8.22.

${ }^{64}$ See Schwitter 2017 on the different contemporary stages in the reception of the letters of late antique epistolographers.
} 
A rare exemplar for Late Antiquity is the exchange between Ausonius and Symmachus: here elaborate harangue meets elaborate counter-harangue; the goal of persuading each of the correspondents consists in convincing the other of his own superiority in the literary field. The contest thrives off the obvious tension arising between the immoderate self-effacement and the brilliance of style of both. ${ }^{65}$

Sidonius and his correspondents, too, greatly affected this game of reciprocal courting. One piled on the compliments and then reacted with feigned modesty. ${ }^{66}$ In this way, it was not only a question of showing respect to the addressee and thereby strengthening the bonds of friendship; the practice in the context of letters of affected courtliness always served the ends of selfpresentation as well. In the often widespread aristocratic networks of friendship in which these letters circulated, one presented oneself as optimus amicus (with, as backdrop, the topos of the letter as a mirror of the soul) and commended oneself thereby to potential, new acquaintances. A certamen mutuae caritatis was also thus always about how one was seen within the peer group in which one moved. The publication of a collection of letters was a means of immortalizing the acquired prestige through the revivifying effects of continual re-enactment through reading.

\section{Aemulatio and the Culture of Literary Competition}

Collections of letters and nugae by authors like Ausonius, Symmachus, and Sidonius yield not only material for the analysis of the culture of literary competition amongst the educated late antique culture but are themselves the intended manifestations of literary aemulatio. This aemulatio is defined by a two-sided competitiveness, which belongs generally to the practice of ancient literature, but seems especially marked in Late Antiquity. This, on the one hand, is the emulative confrontation with the canon of literature passed down and, on the other, with contemporary rivals.

It has been well observed that intertextuality as well as other literary strategies such as fragmenting, hybridizing, and the "jeweled style" belong to the basic principles of late antique poetics and aesthetics. ${ }^{67}$ The various forms and functions, as well as the intentions behind them, and the status of intertextuality have been correspondingly intensively discussed in recent

${ }^{65}$ On this, see Schwitter 2015, 132-37.

${ }^{66}$ For example, Sid. Ap Ep. 7.2.1, 8.9.1, 8.10.

${ }^{67}$ On late antique aesthetics, see, for example, Roberts 1989; Formisano 2007; Schwitter 2015; Elsner and Hernández Lobato 2017; with focus on Sidonius, see Condorelli 2008; Hernández Lobato 2012; Onorato 2016. 
scholarship. ${ }^{68}$ The range of literary rivals to be seen here is considerable: every genre, every literary form, had its own competitive domain with its own particular points of reference. The classical canon formed the measure against which one determined one's own abilities and those of one's fellow competitors. Late antique literary figures were competing essentially over who most closely approached (or even exceeded) the ever defining classical patterns and models of style. This competitive context was quite decisive for the literary self-conception of the time. Sidonius reflects repeatedly in his letters on his own achievements in literature (and in politics) and on those of his friends, where comparison with classical Latin poetry and prose is constantly sought through explicit reference and implicit allusion. ${ }^{69}$ For the reader of Sidonius's collections of letters and of his nugae, therefore, intertextuality functions simultaneously as stage for and marker of this performed, competitive relationship.

Sidonius's Ep. 8.11 to Lupus illustrates how this complex situation of competition can be seen on the micro-level. The epistle is well known for the portrait of the above mentioned poet, Lampridius, and the narrative of his death at the hands of his own slaves. The writing is quite obviously inspired by Pliny's Ep. 3.14, in which the author tells of the murder of his friend, Larcius Macedo, by a slave. ${ }^{70}$ As in the villa letters (Ep. 2.2, 2.9) Sidonius seeks here too a comparison with his declared, emulated model. And yet, Pliny is not the only point of reference implicitly evoked by Ep. 8.11.3: enclosed within the letter is a poem of fifty-eight phalaecian hendecasyllables which Sidonius had once sent ahead as pagina metatoria-a board and lodging letter-on the road to Bordeaux to his friend Lampridius in order to guarantee himself a suitably hospitable reception. Under the nom de plume of "Phoebus," 71 Sidonius instructs the muse Thalia to inform "Orpheus" (referring to Lampridius) of his arrival, and to arrange accommodation for him. Thalia, who symbolizes light and cheerful poetry, sets the tone of the poem. It is as densely allusive as it is artfully enigmatic, and it is marked increasingly towards the end by satirical strokes. This is the first volley by which "Orpheus" is challenged to produce a response in kind. The second challenge plays out at the level of literary tradition: through meter, tone, and other allusions, not only

\footnotetext{
${ }^{68}$ See, for example, Pelttari 2014 and the relevant contributions in McGill and Pucci 2016; Elsner and Hernández Lobato 2017. Regarding Sidonius, the landmark study is Gualandri 1979; see further Mratschek 2017; Hanaghan 2017 and the contributions in Van Waarden and Kelly 2013; Poignault and Stoehr-Monjou 2014.

${ }^{69}$ For example, Sid. Ap. Carm. 9.314-17; Ep. 5.17.1, 8.6, 8.11.5-8, 9.13.1, 9.16.1.

${ }^{70}$ Wolff 2015, 193: "L'imitatio de Pline est évidente: c'est peut-être la lettre de Sidoine où la référence à Pline est la plus nette."

${ }^{71}$ See Stähle in this volume.
} 
Catullus but also Ausonius are first and foremost established as literary lodestars from whom the two friends take their bearings in their literary contest. Although the corresponding text does not survive, there is surely no question that Orpheus/Lampridius took up the friendly, teasing challenge and returned the compliment in a similar fashion.

Competition and rivalry were a natural part of the day-to-day world of the late antique aristocracy. Along with the political and military realms, where one struggled for offices, position, and influence, otium formed a space in which one could and had to measure oneself against equals in games, sports, and literary pursuits. Unlike as in politics, however, the social space of leisure was-clearly, in the literary world of Sidonius Apollinaris at least-not colored by the seriousness of daily life but by common joy and amiable competition in the sancta contentio inter amicos.

\section{Rheinische Friedrich-Wilhelms-Universität Bonn raphael.schwitter@uni-bonn.de}

\section{References}

Anderson, William B., trans. 1936. Sidonius: Poems and Letters. 2 vols. Loeb Classical Library 296 and 420. Cambridge MA: Harvard University Press.

André, Jean-Marie. 1966. L'otium dans la vie morale et intellectuelle à Rome des origines à l'époque augustéenne. Paris: Presses Universitaires du France.

- 2006. "La survie de l'otium litteratum chez Sidoine Apollinaire: culture et lyrisme." In Quesiti, temi, testi di poesia tardolatina. Studien zur klassischen Philologie 153, edited by Luigi Castagna, 63-86. Frankfurt am Main: Peter Lang.

Auhagen, Ulrike. 2003. "Lusus und gloria: Plinius' hendecasyllabi (Epist. 4.14; 5.3 und 7.4)." In Plinius der Jüngere und seine Zeit, edited by Luigi Castagna and Eckard Lefèvre, 3-13. Leipzig: K. G. Saur.

Barton, Carlin A. 2001. Roman Honor: The Fire in the Bones. Berkeley: University of California Press.

Blänsdorf, Jürgen. 1993. "Apollinaris Sidonius und die Verwandlung der römischen Satire in der Spätantike.” Philologus 137: 122-31.

Bruggisser, Philippe. 1993. Symmaque ou le rituel épistolaire de l'amitié littéraire: recheches sur le premier livre de la correspondence. Fribourg: Editions Universitaires Fribourg Suisse.

Condorelli, Silvia. 2008. Il poeta doctus nel 5 secolo d.C.: aspetti della poetica di Sidonio Apollinare. Naples: Loffredo.

- 2013. "Improvisation and Poetical Programme in Sidonius, Ep. 9,13." In New Approaches to Sidonius Apollinaris, edited by Johannes A. van Waarden and Gavin Kelly, 111-32. Leuven: Peeters.

Consolino, Franca Ela. 2011. "Recusationes a confronto: Sidonio Apollinare epist. IX,13,2 e Venanzio Fortunato carm. IX,7.” In Il calamo della memoria, edited by Lucio Cristante, 101-25. Triest: Edizioni Università di Trieste. 
Di Rienzo, Daniele. 2005. Gli epigrammi di Magno Felice Ennodio. Napoli: Dipartimento di Filologia classica F. Arnaldi.

Egelhaaf-Gaiser, Ulrike. 2011. "Bleibende Klänge. Das hymnische Briefsiegel des Bischofs Sidonius.” Millennium Jabrbuch 7: 257-92.

—. 2018. "Vom Epulonenschmaus zum Fest der Worte: Konviviale Gelegenheiten im Briefcorpus des Sidonius." In Zwischen Alltagskommunikation und literarischer Identitätsbildung: Studien zur lateinischen Epistolographie in Spätantike und Frühmittelalter, edited by Gernot M. Müller, 255-85. Stuttgart: Franz Steiner.

Eigler, Ulrich. 2003. Lectiones vetustatis: Römische Literatur und Geschichte in der lateinischen Literatur der Spätantike. Zetemata 115. Munich: Beck.

Elsner, Jaś, and Jesús Hernández Lobato. 2017. The Poetics of Late Latin Literature. Oxford: Oxford University Press.

Fascione, Sara. 2016. "Seronato, Catilina e la moritura libertas della Gallia.” Koinonia 40: 453-62.

Fein, Sylvia. 1993. Die Beziehungen der Kaiser Trajan und Hadrian zu den litterati. Stuttgart: Teubner.

Fisher, Nick, and Hans van Wees. 2011. Competition in the Ancient World. Swansea: The Classical Press of Wales.

Fo, Alessandro. 1999. "Sidonio nelle mani di Eurico (Ep. VIII 9): spazi della tradizione culturale in un nuovo contesto Romanobarbarico." In Memoria del passato, urgenza del future: il mondo romano fra V e VII secolo, edited by Marcello Rotili, 17-39. Napoli: Arte Tipografica.

Formisano, Marco. 2007. "Towards an Aesthetic Paradigm of Late Antiquity." Antiquité Tardive 15: 277-84.

Gibson, Roy. 2013. "Pliny and the Letters of Sidonius: From Constantius and Clarus to Firminus and Fuscus." Arethusa 46.2: 333-55.

Gualandri, Isabella. 1979. Furtiva lectio: studi su Sidonio Apollinare. Milano: Cisalpino-Goliardica.

Guillaume-Coirier, Germaine. 2000. "Des couronnes virgiliennes pour un 'convivium' littéraire: Sidoine Apollinaire, Epist. IX 13,5.” Bulletin de l'Association Guillaume Budé 1: 44-53.

Guipponi-Gineste, Marie-France. 2017. "Le lusus poétique à la lumière du convivium et autres formes d'otium dans les poèmes de la correspondance de Sidoine Apollinaire." In La rhétorique du "petit" dans l'épigramme grecque et latine: actes du colloque de Strasbourg (26-27 mai 2015), edited by Doris Meyer and Céline Urlacher-Becht, 251-66. Paris: Éditions de Boccard.

Hanaghan, Michael. 2017. "Micro Allusions to Pliny and Virgil in Sidonius's Programmatic Epistles." International Journal of the Classical Tradition 24: 249-61.

- 2019. Reading Sidonius' Epistles. Cambridge: Cambridge University Press. Hershkowitz, Debra. 1995. "Pliny the Poet." Greece and Rome 42: 168-81.

Hernández Lobato, Jesús. 2012. Vel Apolline muto: estética y poética de la Antigüedad tardía. Bern: Peter Lang. 
Krasser, Helmut. 1995. "Entwicklungen der römischen Lesekultur in trajanischer Zeit." In Prinzipat und Kultur im 1. und 2. Jahrhundert, edited by Barbara Kühnert, 79-89. Bonn: Rudolf Habelt.

Krostenko, Brian A. 2001. Cicero, Catullus, and the Language of Social Performance. Chicago: University of Chicago Press.

Künzer, Isabelle. 2016. Kulturen der Konkurrenz: Untersuchungen zu einem senatorischen Interaktionsmodus an der Wende vom ersten zum zweiten Jahrhundert $n$. Chr. Bonn: Rudolf Habelt.

La Penna, Antonio. 1993. "Il lusus poético nella tarda antiquità: il caso di Ausonio." In Storia di Roma, vol. 3: l'éta tardoantica-i luoghi e le culture, 731-51. Turin: Einaudi.

- 1995. "Gli svaghi letterari della nobilità gallica nella tarda antichità: il caso di Sidonio Apollinare.” In Maia 47: 3-34.

Le Jan, Régine. 2004. "Le lien social entre Antiquité et haut Moyen Âge: l'amitié dans les collections de lettres gauloise." In Akkulturation: Probleme einer romanischgermanischen Kultursynthese in Spätantike und frühem Mittelalter, edited by Dieter Hägermann, Wolfgang Haubrichs, and Jörg Jarnut, 528-46. Berlin: De Gruyter.

Leach, Eleanor W. 2003. "Otium as Luxuria: Economy of Status in the Younger Pliny's Letters.” Arethusa 36.2: 147-65.

Loyen, André. 1943. Sidoine Apollinaire et l'esprit précieux en Gaule aux derniers jours de l'Empire. Paris: Soc. d'éd. "Les Belles Lettres."

Mattern-Parkes, Susan P. 2001. "Seneca's De ira and the Economy of Honor." In Essays in Honor of Gordon Williams, edited by Elisabeth Tylawsky and Charles Weiss, 177-88. New Haven: Henry R. Schwab Publishers.

Malaspina, Elena. 2002. "Il lusus poetico nella Gallia subromana" In Arma virumque . . . studi di poesia e storiographia in onore di Luca Canali, edited by Emanuele Lelli, 197-233. Pisa: Istituti editoriali e poligrafici internazionali.

Marconi, Giulia. 2013. Ennodio e la nobilità gallo-romana nell'Italia ostrogota. Spoleto: Fondazione Centro italiano di studi sull'alto medioevo.

Mathisen, Ralph Whitney. 1981. "Epistolography, Literary Circles, and Family Ties in Late Roman Gaul." Transactions of the American Philological Society 111: 95-109.

- 1991. "Phoebus, Orpheus and Dionysus: Nicknames and the Literary Circle of Sidonius." In Studies in the History, Literature and Society of Late Antiquity, edited by Ralph Whitney Mathisen, 29-43. Amsterdam: Adolf M. Hakkert.

-1993. Roman Aristocrats in Barbarian Gaul. Austin: University of Texas Press.

McGill, Scott, and Joseph Pucci. 2016. Classics Renewed: Reception and Innovation in the Latin Poetry of Late Antiquity. Heidelberg: Winter.

Moroni, Brunella. 2006. "L'imperatore e il letterato nel Cento nuptialis di Ausonio." Acme 59: 71-100.

Mratschek, Sigrid. 2008. "Identitätsstiftung aus der Vergangenheit: Zum Diskurs über die trajanische Bildungskultur im Kreis des Sidonius Apollinaris.” In Die 
christlich-philosophischen Diskurse der Spätantike, edited by Therese Fuhrer, 363-80. Stuttgart: Steiner.

. 2017. "The Letter Collection of Sidonius Apollinaris.” In Late Antique Letter Collections: A Critical Introduction and Reference Guide, edited by Cristiana Sogno, Bradley K. Storin, and Edward J. Watts, 309-36. Berkeley: University of California Press.

- 2018. "Images of Domitius Apollinaris in Pliny and Martial: Intertextual Discourses as Aspects of Self-Definition and Differentiation." In Roman Literature under Nerva, Trajan and Hadrian: Literary Interactions, AD 96-138, edited by Alice König and Christopher Whitton, 208-32. Cambridge: Cambridge University Press.

Mulligan, Bret. 2018. "Epigrams, Occasional Poetry, and Poetic Games.” In A Companion to Late Antique Literature, edited by Scott McGill and Edward J. Watts, 241-58. New York: Wiley.

Neel, Jaclyn. 2015. Legendary Rivals: Collegiality and Ambition in the Tales of Early Rome. Mnemosyne Supplements 372. Leiden: Brill.

Neger, Margot. 2016. "Die Inszenierung von Mußezeit und Mußeräumen im Briefkorpus des Jüngeren Plinius.” In Muße und Rekursivität in der antiken Briefliteratur, edited by Franziska C. Eickhoff, 133-60. Tübingen: Mohr Siebeck.

Onorato, Marco. 2016. Il castone e la gemma: sulla tecnica poetica di Sidonio Apollinare. Napoli: Paolo Loffredo.

- 2017. "Dal novum al notum: gli anacreontei di Sidonio Apollinare." Bollettino di Studi Latini 47: 112-55.

- 2018. "Un ospite per Apollo: intertestualità interna e codice ausoniano nella metatoria pagina di Sidonio a Lampridio." Bollettino di Studi Latini 48: 492-523.

Pelttari, Aaron. 2014. The Space that Remains: Reading Latin Poetry in Late Antiquity. Ithaca, NY: Cornell University Press.

Poignault, Rémy, and Annick Stoehr-Monjou. 2014. Présence de Sidoine Apollinaire. Clermont-Ferrand: Centre de Recherches A. Piganiol.

Roberts, Michael. 1989. The Jeweled Style: Poetry and Poetics in Late Antiquity. Ithaca, NY: Cornell University Press.

Roller, Matthew. 1998. "Pliny's Catullus: The Politics of Literary Appropriation." Transactions of the American Philological Association 128: 265-304.

Rollinger, Christian. 2014. Amicitia sanctissima colenda: Freundschaft und soziale Netzwerke in der Späten Republik. Heidelberg: Verlag Antike.

Salzman, Michele Renee, and Michael Roberts. 2011. The Letters of Symmachus: Book 1. Society of Biblical Literature. Writings from the Greco-Roman World 30. Atlanta.

Santelia, Stefania, ed. and trans. 2002. Sidonio Apollinare, Propempticon ad libellum: introduzione, traduzione, commento. Bari: Edipuglia.

Schröder, Bianca-Jeanette. 2007. Bildung und Briefe im 6. Jahrhundert. Berlin: De Gruyter.

Schwitter, Raphael. 2015. Umbrosa lux: Obscuritas in der lateinischen Epistolographie der Spätantike. Hermes Einzelschriften 107. Stuttgart: Steiner. 
2016. "Der obszöne Leser: Vergilkritik und apologetische Strategie in Ausonius' Cento nuptialis, 101-3." Museum Helveticum 73: 192-210.

- 2017. "Letters, Writing Conventions, and Reading Practices in the Late Roman World: Analysing Literary Reception in Late Antiquity and Beyond.” Linguarum Varietas 6: 61-77.

Shanzer, Danuta. 2001. "Bishops, Letters, Fast, Food, and Feast in Later Roman Gaul.” In Society and Culture in Late Antique Gaul, edited by Ralph W. Mathisen and Danuta Shanzer, 217-36. Burlington, VT: Ashgate.

Simons, Roswitha. 2008. "Sidonius' Satirenbrief epist. 1,11: Berechtigung und Grenzen des Spotts in der römischen Rhetorik.” In Streitkultur: Okzidentale Traditionen des Streitens in Literatur, Geschichte und Kunst, edited by Uwe Baumann, Arnold Becker, and Astrid Steiner-Weber, 79-95. Göttingen: V \& R Unipress.

Sowers, Brian P. 2016. "Amicitia and Late Antique Nugae: Reading Ausonius' Reading Community." American Journal of Philology 137: 511-40.

Styka, Jerzy. 2015. "Late Ancient Collegia Poetarum according to Sidonius Apollinaris." Classica Cracoviensia 18: 377-90.

- 2016. "Inter amicos inter aequales . . . : The Reflections of Sidonius Apollinaris (Fifth Century AD) on the Élite Consciousness of Gallo-Roman Nobles in the Period of Barbarian Invasions." In De amicitia: Transdisciplinary Studies in Friendship, edited by Katarzyna Marciniak and Elzbieta Olechowska, 351-68. Warsaw: Faculty of "Artes Liberales," University of Warsaw.

Van Waarden, Johannes A., and Gavin Kelly, eds. 2013. New Approaches to Sidonius Apollinaris. Leuven: Peeters.

Wiegandt, Dirk. 2016. “Otium als Mittel der literarischen Selbstinszensierung römischer Aristokraten in Republik und Früher Kaiserzeit.” In Muße und Rekursivität in der antiken Briefliteratur, edited by Franziska C. Eickhoff, 43-57. Tübingen: Mohr Siebeck.

Wiseman, Timothy P. 1985. Roman Political Life, 90 B.C.-A.D. 68. Exeter: University of Exeter Press.

Wolff, Étienne. 2015. "La lettre VIII, 11 de Sidoine Apollinaire sur le rhéteur Lampridius." In Caritatis scripta: mélanges de littérature et de patristique offerts à Patrick Laurence, edited by Aline Canellis, Élisabeth Gavoille, and Benoît Jeanjean, 191-97. Paris: Institut d'Études Augustiniennes.

Wood, Ian. 2000. "The Exchange of Gifts among Late Antique Aristocracy." In El Disco de Teodosio, edited by Martín Almagro-Gorbea, José Maria Álvarez Martínez, and José Maria Blázquez, 301-14. Madrid: Real Academia de la Historia. 